\title{
Enzyme-assisted extraction of red seaweed Solieria chordalis (C.Agardh) J. Agardh 1842-the starting point for the production of biostimulants of plant growth and biosorbents of metal ions
}

\author{
Olivia Spain ${ }^{1} \cdot$ Kevin Hardouin ${ }^{1} \cdot$ Nathalie Bourgougnon ${ }^{1}\left[\right.$ - Izabela Michalak ${ }^{2}(\mathbb{D}$
}

Received: 4 November 2021 / Revised: 4 February 2022 / Accepted: 9 February 2022

(c) The Author(s) 2022

\begin{abstract}
The underexploited biomass of red seaweed Solieria chordalis (C.Agardh) J.Agardh 1842 represents a potential source for biotechnological development. Extracts obtained from S. chordalis by enzyme-assisted extraction using Protamex® and Neutrase ${ }^{\circledR}$ were evaluated as potential biostimulants of plant growth. Additionally, this alga, as well as post-extraction residues, were examined as biosorbents of metal ions. The biostimulant properties of different concentrations of algal extracts $(20,40,60,80,100 \%)$ were tested in vitro on radish seeds. Chlorophyll content, plant weight, and height were measured for each experimental group. For all tested concentrations, the plants demonstrated higher chlorophyll content and were higher and heavier than the control group, showing that enzyme extracts could be used as efficient biostimulants. The biosorption properties of seaweed and post-extraction residues were tested on $\mathrm{Cr}(\mathrm{III})$ ions for different experimental conditions- $\mathrm{pH}$, initial metal ion concentration, and biosorbent dosage. The maximum biosorption capacity of $S$. chordalis was $48.1 \mathrm{mg} / \mathrm{g}$, for the post-extraction residue obtained with Protamex ${ }^{\circledR}, 47.6 \mathrm{mg} / \mathrm{g}$, and Neutrase ${ }^{\circledR}, 50.5 \mathrm{mg} / \mathrm{g}$. The binding of $\mathrm{Cr}(\mathrm{III})$ ions to the surface of biosorbents was confirmed by FT-IR analysis. Good biosorption properties of tested materials can be used in the production of novel components of fertilizers or biosorbents for wastewater treatment. In this paper, it was shown that waste biomass of $S$. chordalis can be turned into valuable bio-products using environmental-friendly technologies.
\end{abstract}

Keywords Red seaweed $\cdot$ Solieria chordalis $\cdot$ Enzyme-assisted extraction $\cdot$ Post-extraction residue $\cdot$ Biostimulation . Biosorption

\section{Introduction}

With increasing pressure being put on the agricultural industry to produce more and more food for the growing population, new sustainable and eco-friendly solutions need to be found to increase crop productivity and harvest yield. Chemical fertilizers and pesticides were an effective short-term solution, but their long-term effects are starting to show, e.g., decrease

Nathalie Bourgougnon

nathalie.bourgougnon@univ-ubs.fr

$\triangle$ Izabela Michalak

izabela.michalak@pwr.edu.pl

1 Laboratoire de Biotechnologie Et Chimie Marines, EA3884, UBS, IUEM, F-56000 Vannes, France

2 Department of Advanced Material Technologies, Faculty of Chemistry, Wrocław University of Science and Technology, Smoluchowskiego 25, 50-372 Wrocław, Poland in soil quality, and accumulation of toxic metals in the soil [1, 2]. Currently, there is a tendency to search for a new generation of agro-products manufactured from raw materials of biological origin [3-5]. Algal products (e.g., extracts) that improve the uptake of minerals from the soil and increase the resistance of plants to biotic and abiotic stress can contribute to the reduction of chemicals used in agriculture [6-8]. Combined with more precise dosing of mineral fertilizers and synthetic plant protection products, they will have a positive impact on the natural environment [9]. These products have advantages over chemical fertilizers in that they have a longer shelf life, are easy to handle, have high moisture retention capacity, influence high soil fertility by humus formation, and are significantly cheaper. The current commercial extracts for example Ekologik R (Chile), Kelpak 66 (South Africa), Maxicrop (UK), Seasol (Australia), Goemill (France), AlgaminoPlant (Poland), and Acadian (Canada) are manufactured mainly from brown seaweeds like Ascophyllum nodosum, Laminaria spp., Saccorhiza spp., Ecklonia maxima, Fucus spp., 
Sargassum spp., and Durvillaea spp. However, although there are more than 9000 species of macroalgae in the world, very few red seaweed species have been studied for these types of agricultural applications.

Among the marine flora encountered in Europe, some macroalgae can become invasive or proliferative and have profound adverse ecological impacts [10]. Over the past few years, the red macroalga Solieria chordalis has been observed in the Gulf of Morbihan and in the Sarzeau peninsula (France). Local wind and tides drive seaweeds to the shore, causing economical losses and the destruction of coastal marine habitats. During the summertime and until December, over 15,000 tons of seaweed are removed, mainly composed of $S$. chordalis [11, 12]. This macroalga is proposed to be used in various applications such as medicine (immunological and antiviral activities) [13-15], nutraceuticals, and cosmetics [16, 17]. Currently, in South Brittany (France), the only exploitation of this biomass relates to agricultural amendment applications in nearby fields. Given the current interest in new bio-products from renewable sources, this underexploited biomass represents a potential source for biotechnological development in agricultural products.

In the present study, enzyme-assisted extraction of Solieria chordalis was proposed as a method of biomass valorization. This eco-friendly approach enables the production of a watersoluble extract, which is rich in sulfated polysaccharides and proteins $[14,18,19]$. This extract can be used as a biostimulant of plant growth. Enzyme-assisted extraction also produces a post-extraction residue, which has not been used on a large scale so far. Considering the idea of bio-based economy and sustainable development, this residue, depending on chemical composition, can be valorized into many value-added products such as sorbents of metal ions, soil improvers, and feed additives $[4,5]$. Therefore, through this study, we used an up-andcoming and environmentally responsible extraction method to fully exploit both the resulting extract and the resulting residue, with the goal of creating biostimulants and biosorbents through a zero-waste biorefinery approach.

To achieve this goal, enzyme extracts obtained from Solieria chordalis with two proteases Protamex ${ }^{\circledR}$ and Neutrase ${ }^{\circledR}$ were examined in germination tests on radish to determine their potential phytotoxicity as well as effect on plant growth (e.g., plant weight, length, chlorophyll content). On the other hand, the seaweed biomass itself, as well as the obtained post-extraction residue, was tested for sorption properties using aqueous solutions of $\mathrm{Cr}(\mathrm{III})$ ions.

\section{Materials and methods}

\subsection{Materials}

The macroalga Solieria chordalis (Rhodophyta, Gigartinales) was collected by hand in October 2018 on the coastlines of Saint Gildas de Rhuys (Brittany, France). The GPS coordinates of the beach are $47^{\circ} 29^{\prime} 30.5^{\prime \prime}$ north (latitude) and a longitude of $2^{\circ} 49^{\prime} 52.0^{\prime \prime}$ west. The fresh biomass was rinsed to remove impurities, left to air-dry for $24 \mathrm{~h}$, and ground.

\subsection{Enzyme-assisted extraction}

Two commercial enzymatic preparations (Protamex $®$; endoprotease EC 3.4.21.62 and Neutrase ${ }^{\circledR}$; metallo-endoprotease EC 3.4.22), provided by Novozymes (Bagsværd, Denmark), were used for the enzyme-assisted extraction of seaweed. The extractions were performed in bioreactors. Enzymeassisted extraction (EAE) was achieved in a final volume of $950 \mathrm{~mL}$ with $50 \mathrm{~g}$ of freeze-dried $S$. chordalis and the rest constituted distilled water. Extractions were carried out with an enzyme/seaweed ratio of 5/100 (5\% d.w. or $2.5 \mathrm{~g}$ of enzyme), for $3 \mathrm{~h}$ at $50{ }^{\circ} \mathrm{C}$. Enzymes were then denatured by rising the temperature to $85^{\circ} \mathrm{C}$ for $15 \mathrm{~min}$. The obtained water-soluble extracts were filtered, separated from the washed residue, and freeze-dried. Each extraction was performed in duplicate. The extracts were filtered via a Büchner filtration system and two fractions, i.e., supernatant and post-extraction residue, were obtained. All samples were freeze-dried.

\subsection{Analysis of biochemical composition}

Acid and aqueous extractions were performed on the enzyme extracts and post-extraction residues. Ten milligrams of lyophilized EAE extract was finely ground and mixed with $5 \mathrm{~mL}$ of hydrochloric acid $(1 \mathrm{M})$ in a sealed vial. The step was repeated 3 times for each extract. The vials were then heated at $100{ }^{\circ} \mathrm{C}$ for $2 \mathrm{~h}$, with manual shaking every $30 \mathrm{~min}$. After $2 \mathrm{~h}$, the solution was neutralized by the addition of $5 \mathrm{~mL}$ of $1 \mathrm{M}$ sodium hydroxide and this solution was then used to quantify proteins, sugars, and uronic acids present in the algal sample. The same extraction experiment was performed in ultrapure water and the aqueous solution was used to quantify sulfate groups present in the algal sample. Colorimetric methods were used to quantify the amounts of these compounds in the hydrolyzed extracts and postextraction residues. All quantification assays were done in triplicate. Proteins were quantified using a Micro BCA Protein Assay kit (PierceTM, Thermo Scientific) [20], a method based on the Biuret reaction. The bovine serum albumin 
was used as the standard, in a range of 0 to $1000 \mu \mathrm{g} / \mathrm{mL}$. The absorbance was measured at $540 \mathrm{~nm}$ in a microplate reader (Multiskan GO, Thermo Scientific). The neutral sugars were quantified by the phenol sulfuric acid method reported by Dubois (1956). Glucose was used as standard in a range of 0 to $100 \mu \mathrm{g} / \mathrm{mL}$, and the absorbance measured at $490 \mathrm{~nm}$ [21]. Sulfate groups were quantified by the Azure A method [22]. The dextran sulfate, containing 43\% of sulfate groups (w/w), was used as standard in a range of 0 to $43 \mu \mathrm{g}$ of sulfate $/ \mathrm{mL}$, and the absorbance measured at $535 \mathrm{~nm}$. The quantity of uronic acids was measured via the meta-hydroxy-di-phenyl method [23]. Glucuronic acid was used as standard in a range of 0 to $200 \mu \mathrm{g} / \mathrm{mL}$, and the absorbance measured at $525 \mathrm{~nm}$. Finally, the ash content was determined thermogravimetrically after calcination of samples at $700{ }^{\circ} \mathrm{C}$ for $2 \mathrm{~h}$.

\subsection{Germination tests with enzyme extracts}

The freeze-dried algal extracts obtained with Protamex ${ }^{\circledR}$ and Neutrase ${ }^{\circledR}$ were redissolved in deionized water as to obtain the initial concentration $(100 \% ; 2.85 \mathrm{~g}$ of extract in $100 \mathrm{~mL}$ of water) then used as potential biostimulants of plant growth. Later, $100 \%$ extract concentration was diluted with distilled water to get the $20-100 \%$ concentration range. Germination tests were performed on radish seeds (Raphanus sativus L.) in Petri dishes (diameter $9 \mathrm{~cm}$ ). Twenty-five seeds were evenly dispersed on cotton $(1 \mathrm{~g})$ in each Petri dish. Every dish was watered with $2 \mathrm{~mL}$ of the appropriate algal extract, or with $2 \mathrm{~mL}$ of distilled water for the control group. The concentrations of algal extract tested were $20,40,60,80$, and $100 \%$ and each concentration was tested in 4 repetitions $(N=4)$. All dishes were placed under optimal conditions for plant growth, i.e., with the appropriate lighting (12:12) and temperature. The dishes were watered every 3 days with $6 \mathrm{~mL}$ of distilled water for the next 9 days. On the 10th day, the germinated and ungerminated seeds in each dish were counted and the sprouts from each dish were measured, weighed, and tested for chlorophyll content. Plant length of all germinated seeds in a given group was measured with a ruler. Fresh weight is presented as the mean weight of radish seedlings that germinated in each repetition in each experimental group $(N=4)$. The chlorophyll content was measured with a SPAD-502 m (Konica Minolta, Japan), a convenient hand-held system which measures the absorbance of the leaves without damaging them.

\subsection{Biosorption experiments}

\subsubsection{Biosorption kinetics}

The whole biomass of Solieria chordalis, as well as postextraction residues used for the biosorption experiments, was sieved through a 400- $\mu \mathrm{m}$ mesh (Retsch, Germany). Solutions of $\mathrm{Cr}(\mathrm{III})$ ions were prepared in deionized water at different concentrations $(100,200,300$, and $400 \mathrm{mg} / \mathrm{L})$, by dissolving appropriate amounts of $\mathrm{Cr}\left(\mathrm{NO}_{3}\right)_{3} \cdot 9 \mathrm{H}_{2} \mathrm{O}$ (Honeywell Fluka ${ }^{\mathrm{TM}}$ ). The concentration that demonstrated the best biosorption properties was then tested at different $\mathrm{pH}$ $(3,4$, and 5) and at different concentrations of biosorbent (1 and $2 \mathrm{~g} / \mathrm{L}$ ). $\mathrm{pH}$ was measured with Mettler-Toledo $\mathrm{pH}$ meter (Seven Multi; Greifensee, Switzerland). The experiments on biosorption kinetics were performed in 250-mL Erlenmeyer flasks containing $200 \mathrm{~mL}$ of $\mathrm{Cr}$ (III) ion solution and the appropriate quantity of biosorbent. The solutions were put on a shaker at $200 \mathrm{rpm}$ for $3 \mathrm{~h}$. During biosorption, samples were taken after $5,10,15,30,45,60,75,90,105,120$, 150, and $180 \mathrm{~min}$. Each sample was immediately filtered through filter paper (Munktell Ahlstrom, 110-mm diameter grade 1290). Four milliliters of each filtered sample was then added to a glass test tube containing $0.095 \mathrm{~g}$ of ethylenediaminetetraacetic acid (Avantor Performance Materials, Gliwice, Poland) and put into a water bath at $95{ }^{\circ} \mathrm{C}$ for $10 \mathrm{~min}$. The samples were analyzed by spectrophotometry (UV-Vis spectrophotometer; V-5000, Shanghai Metash Instruments Co., Shanghai, China) at a wavelength of $540 \mathrm{~nm}$ to determine the concentration of $\mathrm{Cr}(\mathrm{III})$ ions in the solution before and after biosorption process. Biosorption capacity ( $q$; $\mathrm{mg} / \mathrm{g}$ ) of the Solieria chordalis and post-extraction residues was determined from Eq. (1):

$q=\left(C_{0}-C_{\mathrm{t}}\right) \cdot V / W$

where $C_{0}(\mathrm{mg} / \mathrm{L})$ and $C_{\mathrm{t}}(\mathrm{mg} / \mathrm{L})$ are initial and after defined time $t(\mathrm{~min})$ concentrations of $\mathrm{Cr}$ (III) ions in the solution, respectively; $W(\mathrm{~g})$ is the mass of biosorbent used for sorption and $V(\mathrm{~L})$ is the volume of the solution.

For description of biosorption kinetics, the pseudo-second-order model, presented in Eq. 2 [24] was used:

$\frac{d q_{t}}{d t}=k_{2} \cdot\left(q_{\mathrm{eq} 2}-q_{\mathrm{t}}\right)^{2}$

where $q_{\mathrm{eq} 2}$ and $q_{\mathrm{t}}$ are the amount of adsorbed metal ions $(\mathrm{mg} / \mathrm{g})$ at equilibrium and at time $t$ respectively; $k_{2}$ is the rate constant of the pseudo-second-order model of biosorption ( $\mathrm{g} / \mathrm{mg} \cdot \mathrm{min}$ ). The parameters $q_{\mathrm{eq} 2}$ and $k_{2}$ can be calculated from the linearization of this model (3):

$\frac{t}{q_{t}}=\frac{1}{k_{2} \cdot q_{\mathrm{eq} 2}^{2}}+\frac{t}{q_{\mathrm{eq} 2}}$

\subsubsection{Biosorption equilibrium}

Equilibrium experiments were carried out in Erlenmeyer flasks each containing $\mathrm{Cr}$ (III) ion aqueous solutions at different concentrations $(25,50,100,150,200,250$, and 
$300 \mathrm{mg} / \mathrm{L}$ ). The parameters used for the equilibrium experiments were chosen based on the results from the kinetic experiments $\left(C_{\mathrm{S}} 1 \mathrm{~g} / \mathrm{L}\right.$ and $\left.\mathrm{pH} 5\right)$. The Erlenmeyer flasks were put on a shaker for $2 \mathrm{~h}$ (time determined in kinetic studies) at room temperature and the concentration of $\mathrm{Cr}$ (III) ions before and after biosorption was also determined spectrophotometrically as for biosorption kinetics.

The Langmuir model (Eq. 4), assuming the monolayer adsorption of sorbate on the sorbent, was used for the interpretation of biosorption equilibrium [25].

$q_{\mathrm{eq}}=\frac{q_{\mathrm{max}} b C_{\mathrm{eq}}}{1+b C_{\mathrm{eq}}}$

where $q_{\max }$ is the maximum biosorption capacity ( $\mathrm{mg} / \mathrm{g}$ ) corresponding to complete monolayer coverage on the sorbent surface, $b$ is the Langmuir adsorption constant $(\mathrm{L} / \mathrm{mg})$, and $C_{\text {eq }}$ is the residual metal ion concentration at equilibrium $(\mathrm{mg} / \mathrm{L})$.

\subsubsection{FT-IR analysis of sorbents before and after biosorption of $\mathrm{Cr}(\mathrm{III})$ ions}

To determine which functional groups on the surface of Solieria chordalis, Protamex ${ }^{\circledR}$, and Neutrase ${ }^{\circledR}$ post-extraction residues were implicated in the biosorption of $\mathrm{Cr}(\mathrm{III})$ ions, FT-IR analysis was performed. For this reason, algal biomass was enriched with $\mathrm{Cr}(\mathrm{III})$ ions with the most optimal experimental parameters determined in the kinetic studies $(300 \mathrm{mg} / \mathrm{L}, \mathrm{pH} 5,2 \mathrm{~h}, 200 \mathrm{rpm})$. After filtration, the enriched algal biomass was dried. The FTIR spectra were recorded on a Nicolet iS5 FTIR spectrometer (Thermo Scientific) using an iD7 ATR module with a diamond crystal. All spectra resulted from 32 scans and a resolution of $1.928 \mathrm{~cm}^{-1}$ from 400 to $4000 \mathrm{~cm}^{-1}$. The OMNIC software was used for data acquisition (transmission mode). A background reference was obtained before each sample measurement. Data treatment was performed with the Unscrambler $\mathrm{X}$ software (CAMO). The spectra were studied both on their full range $\left(400-4000 \mathrm{~cm}^{-1}\right)$ and on a selected zone of interest $\left(700-1700 \mathrm{~cm}^{-1}\right)$.

\subsection{Statistical analysis}

Results from the germination tests were statistically elaborated with Statistica 13 software (TIBCO Software Inc., Tulsa, OK, USA). The obtained data was analyzed with the Shapiro-Wilk normality test. If the distribution was normal, homogeneity of variances was verified with the Brown-Forsyth test. A Tukey test was then used to compare any differences between the different groups tested, and, more specifically, to compare all pairs of means following one-way ANOVA tests (results presented as a mean and standard deviation). In the case of a non-normal distribution, the Mann-Whitney test (to compare two groups) or the Kruskal-Wallis test (to compare more than two groups) were used (results presented as a median). Results were considered significantly different when $p<0.05$.

\section{Results and discussion}

In this study, we aimed to create an innovative biorefinery concept. Enzyme-assisted extraction, a cost-effective and eco-friendly process, was used to produce sustainable liquid plant biostimulant(s) from the biomass of red seaweed Solieria chordalis. The use of enzyme extraction, as opposed to other more traditional extraction methods, can protect important biomass components, e.g., carbohydrates against degradation [18]. The post-extraction residue, considered until now as waste, was instead recognized here as a valuable by-product due to its promising biosorption properties. In the future, these properties could be used to develop innovative solutions for bioremediation of polluted water and soil or in agriculture as a carrier of microelements.

\subsection{Total yield of enzyme-assisted extraction}

The gross extraction yield can be defined as the yield at the end of the whole experimental process. Its calculation considers the loss of matter during freezing, grinding, and heating (hydrolysis and denaturation). However, it does not take into consideration the residual hydrolysate fraction present in the solid residue after filtration nor the extra dry matter related to the addition of the enzymatic preparations. The extraction yield is therefore based on the quantity of dry matter present in the filtered hydrolysate. In the case of Neutrase ${ }^{\circledR}, 51.5 \%$ of the algal compounds were solubilized into the supernatant. Therefore, $27.1 \mathrm{~g}$ of soluble compounds went into the supernatant phase and $25.4 \mathrm{~g}$ of insoluble compounds were left in the post-extraction residue. For Protamex ${ }^{\circledR}$, the yield was marginally higher as the enzyme was capable of solubilizing $1.54 \%$ more compounds than Neutrase ${ }^{\circledR}$, with a total of $27.9 \mathrm{~g}$ of soluble compounds in the supernatant and $24.6 \mathrm{~g}$ of insoluble compounds in the post-extraction residue. Similar results have already been observed by Hardouin et al. (2014) and Burlot et al. (2016) $[14,18]$. Even though the yield values were slightly different, due to some differences in the protocols used, Protamex ${ }^{\circledR}$ also gave higher extraction yields than Neutrase. However, both increased the extraction yields as compared to a control processed in similar experimental conditions without enzymes $[14,18]$. 


\subsection{Biochemical composition of enzymatic algal extracts and post-extraction residues}

As shown in the work of Burlot et al. (2016), Solieria chordalis is composed essentially of water (up to $90 \%$ ). The dry matter is rich in ash (43.3\%) and sulfated polysaccharides (about 49.5\%), whereas lipids represent a small percentage of the seaweed's dry weight (3.0\%). Proteins constitute about $22 \%$ of the dry matter [18]. Table 1 shows the biochemical composition of enzyme extracts obtained from Solieria chordalis with Neutrase ${ }^{\circledR}$ and Protamex $\AA$, as well as the biochemical composition of the post-extraction residues.

The composition of both enzyme extracts is comparable. Sugars are an abundant ingredient in both extracts. Seaweed polysaccharides and their derived oligosaccharides are known to stimulate plant growth (seed germination, shoot and root length, shoot and root dry weight, and the biosynthesis of chlorophyll in plants) and can also act as water holders [26]. The possible mechanism is the enhancement of basal metabolism, assimilation of carbon and nitrogen, plant cell division, etc. [27]. Mzibra et al. (2018) showed that a conventional hot water method under neutral conditions enabled extraction of mainly neutral sugars (glucose, maltose, galactose) and sulfate from red seaweeds (Gigartina sp., Gigartina pistillata, Schizymenia dubyi, Chondracanthus acicularis, Gelidium crinale, Plocamium cartilagineum, Gracilaria multipartita). The content of glucose in the extract ranged from 15 to $44.6 \%$, maltose from 12.4 to $39.6 \%$, galactose from 27.4 to $56.2 \%$, and sulfate from 5.5 to $7.6 \%$ depending on seaweed species [26]. These data are in agreement with the results obtained for Solieria chordalis.

It is worth noting that the Solieria post-extraction residue also has a valuable composition. The Neutrase ${ }^{\circledR}$ postextraction residue contained $9.8 \%$ more mineral matter and $9 \%$ more proteins than the Protamex ${ }^{\circledR}$ post-extraction residue. The Neutrase ${ }^{\circledR}$ residue was also characterized by a higher amount $(6.3 \%)$ of sulfate groups than Protamex ${ }^{\circledR}$ post-extraction residue, which can influence their biosorption properties. Sulfate groups (from sulfated polysaccharides, e.g., carrageenan) together with amino, carboxyl, and hydroxyl groups from other macromolecules participate in the binding of metal ions from aqueous solutions during biosorption [28-31]. Additionally, sulfate groups in polysaccharides may improve plant growth since sulfur is one of the main macroelements essential for plant growth (component of enzymes, vitamins, participation in chlorophyll formation) [26].

\subsection{Evaluation of the biostimulant properties of enzyme extracts}

Solieria chordalis extract obtained by EAE with two enzymes Neutrase $\AA$ and Protamex ${ }^{\circledR}$ was applied on radish seeds in different concentrations $(20,40,60,80$, and $100 \%)$ in order to determine if the extracts are phytotoxic to plants and if they can stimulate seed germination, plant growth, and development. For Neutrase ${ }^{\circledR}$, the experimental groups for the individual concentrations were labeled as $\mathrm{N}-20 \%$, $\mathrm{N}-40 \%, \mathrm{~N}-60 \%, \mathrm{~N}-80 \%$, and N-100\%, and for Protamex ${ }^{\circledR}$ as $\mathrm{P}-20 \%, \mathrm{P}-40 \%, \mathrm{P}-60 \%, \mathrm{P}-80 \%$, and $\mathrm{P}-100 \%$.

\subsubsection{Germination percentage of radish seeds treated with enzyme algal extracts}

Figure 1 presents the number of germinated seeds in all examined groups tested in four replications.

The results are presented as a median, as no normal distribution was demonstrated for the tested data. The highest median of germinated normal seedlings was obtained when the seeds were treated with $20 \%$ algal extracts for Neutrase ${ }^{\circledR}$ (14.3) and 40\% for Protamex ${ }^{\circledR}$ (16.3), and these values were higher than those in the control group (11.3) by $26.5 \%$ and $44.2 \%$, respectively. It was observed that the number of germinated seeds generally decreased with the increase in extract concentration. Comparing both extracts, better results were obtained for enzymatic hydrolysis with Protamex ${ }^{\circledR}$. For this extract, the number of germinated seeds for all tested concentrations was higher than that in the control group treated with distilled water.

Table 1 The biochemical composition of enzymatic algal extracts and post-extraction residues

\begin{tabular}{|c|c|c|c|c|c|c|c|}
\hline Product/composition & & Mineral matter (ash) & Sugars & Sulfate groups & Proteins & Other & Recovery \\
\hline \multirow{2}{*}{$\begin{array}{l}\text { Neutrase }{ }^{\circledR} \\
\text { Extract }\end{array}$} & $\%$ & $49.2 \pm 0.7$ & $21.4 \pm 0.3$ & $5.80 \pm 0.10$ & $5.33 \pm 0.40$ & $18.2 \pm 1.5$ & \multirow[t]{2}{*}{$81.8 \%$} \\
\hline & $\mathrm{g}$ & $13.3 \pm 0.2$ & $5.79 \pm 0.1$ & $2.90 \pm 0.05$ & $1.44 \pm 0.10$ & $3.62 \pm 0.45$ & \\
\hline \multirow{2}{*}{$\begin{array}{l}\text { Protamex }{ }^{\circledR} \\
\text { Extract }\end{array}$} & $\%$ & $49.5 \pm 0.8$ & $20.2 \pm 0.3$ & $5.48 \pm 0.10$ & $5.82 \pm 0.50$ & $19.1 \pm 1.7$ & \multirow[t]{2}{*}{$81.0 \%$} \\
\hline & $\mathrm{g}$ & $13.8 \pm 0.2$ & $5.61 \pm 0.1$ & $2.82 \pm 0.05$ & $1.62 \pm 0.10$ & $4.03 \pm 0.45$ & \\
\hline $\begin{array}{l}\text { Neutrase }{ }^{\circledR} \\
\text { post-extraction residue }\end{array}$ & $\mathrm{g}$ & $5.39 \pm 0.3$ & $10.1 \pm 0.1$ & $4.53 \pm 0.10$ & $6.78 \pm 0.20$ & l & l \\
\hline $\begin{array}{l}\text { Protamex }{ }^{\circledR} \\
\text { post-extraction residue }\end{array}$ & $\mathrm{g}$ & $4.91 \pm 0.3$ & $10.3 \pm 0.1$ & $4.26 \pm 0.10$ & $6.22 \pm 0.20$ & l & I \\
\hline
\end{tabular}




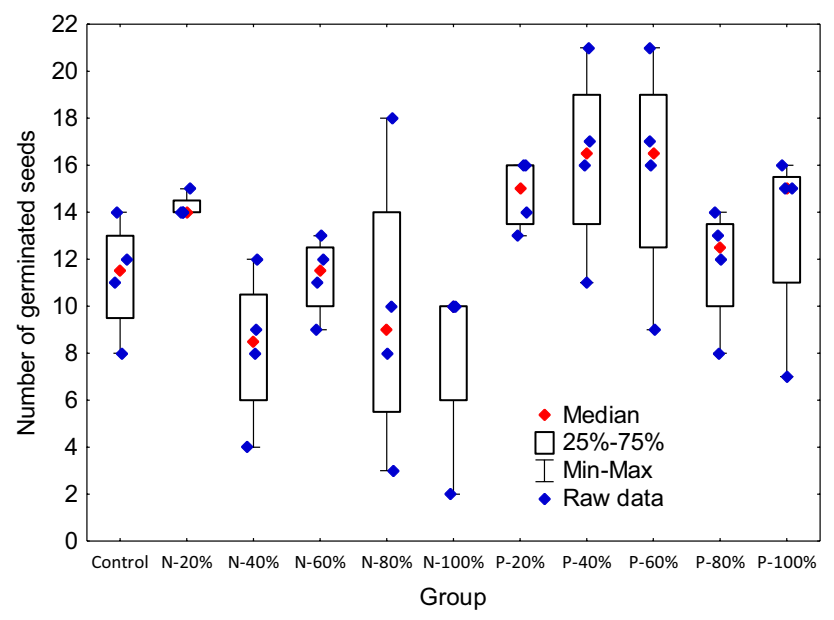

Fig. 1 Number of germinated seeds in the tested groups

Seaweed extracts are known to promote increased germination rates and germination percentage as well as enhancing seedling vigor [8]. Mzibra et al. (2018) confirmed that polysaccharide-enriched extracts produced from red seaweeds Gigartina sp., Schizymenia dubyi, Chondracanthus acicularis, Gelidium crinale, Plocamium cartilagineum, and Gracilaria multipartita applied at a dose of $0.2 \mathrm{mg} / \mathrm{mL}$ accelerated the germination of tomato seeds [26]. Di FilippoHerrera et al. (2018) did not find any relationship between the red seaweed extract concentration $(0.06,0.12,0.25,0.5$, 1 , and $2 \%$ ) and seed germination. The alkaline extract at a concentration of $0.5 \%$ from Acanthophora spicifera and Gelidium robustum reduced the mung bean (Vigna radiata) germination, as well as 2\% from Gracilaria parvispora [32]. Generally, seaweed-derived oligosaccharides can increase the activity of germination enzymes and accelerate seed metabolic activity [33]. Oligosaccharides stimulate plant growth by enhancing carbon and nitrogen assimilation, basal metabolism, and cell division as well as the level of phenylpropanoid compounds (PPC) with antimicrobial properties, which allows for an additional protection against microbial pathogens [27, 33, 34]. Increased germination percentage can also be attributed to the more efficient water uptake by seeds treated with seaweed polysaccharide-enriched extracts [26].

\subsubsection{Stimulation of radish growth by Solieria enzyme extracts}

The effect of algal extracts on the length, fresh weight, and chlorophyll content in radish seedlings is presented in Table 2.

Effect of enzyme algal extracts on the length of radish seedlings Figure 2 and Table 2 present the effect of different concentrations of algal extracts on the radish seedlings' length. The middle value of a dataset is presented as a median due to the lack of normal distribution. The highest number of germinated seeds, as well as the longest plants, was observed in the group treated with Protamex® extract. All concentrations of this extract (with the exception of $80 \%$ ) gave longer plants than the control group. The best results were obtained for $40 \%$ (statistically significant difference when compared to the control group). A significant difference $(p<0.05)$ was also determined between P-40\% and P-80\%. Differences in plant length were not as apparent when using the extract obtained with Neutrase ${ }^{\circledR}$. For this extract, the highest plant length was obtained for the concentration of $100 \%$, and it was slightly higher (by 8.7\%) than that in the control group (but not statistically significant). A statistically significant difference was observed between the $\mathrm{N}-100 \%$ and $\mathrm{N}-40 \%$ group.

The positive effect of alkaline extracts obtained from red seaweeds Gelidium robustum and Gracilaria parvispora on the length of mung bean (Vigna radiata) was observed by Di Filippo-Herrera et al. (2018) [32]. The authors indicated that $2 \%$ extract from G. robustum and $0.06 \%$ from $G$. parvispora showed a significant increase in plant length by
Table 2 The effect of different concentrations of algal extracts produced with Neutrase ${ }^{\circledR}$ and Protamex ${ }^{\circledR}$ on radish growth and chlorophyll content in seedlings

\begin{tabular}{|c|c|c|c|c|c|c|}
\hline \multirow[t]{2}{*}{ Group } & \multicolumn{2}{|c|}{$\begin{array}{l}\text { Length of radish seedlings } \\
(\mathrm{cm})\end{array}$} & \multicolumn{2}{|c|}{$\begin{array}{l}\text { Fresh weight of radish seed- } \\
\text { lings }(\mathrm{g})\end{array}$} & \multicolumn{2}{|c|}{$\begin{array}{l}\text { Chlorophyll content in radish } \\
\text { seedlings (SPAD) }\end{array}$} \\
\hline & $\begin{array}{l}\text { Neutrase } \AA \\
(\mathrm{N}) \\
\text { Median }\end{array}$ & $\begin{array}{l}\text { Protamex® } \\
(\mathrm{P}) \\
\text { Median }\end{array}$ & $\begin{array}{l}\text { Neutrase }{ }^{\circledR} \\
(\mathrm{N}) \\
\text { Mean } \pm \mathrm{SD}\end{array}$ & $\begin{array}{l}\text { Protamex }{ }^{\circledR} \\
(\mathrm{P}) \\
\text { Mean } \pm \mathrm{SD}\end{array}$ & $\begin{array}{l}\text { Neutrase }{ }^{\circledR} \\
(\mathrm{N}) \\
\text { Mean } \pm \text { SD }\end{array}$ & $\begin{array}{l}\text { Protamex }{ }^{\circledR} \\
(\mathrm{P}) \\
\text { Median }\end{array}$ \\
\hline Control & 2.3 & $2.3^{\mathrm{a}}$ & $0.63 \pm 0.28$ & $0.63 \pm 0.28^{\mathrm{a}}$ & $39.6 \pm 14.2^{\mathrm{a}, \mathrm{b}, \mathrm{c}, \mathrm{d}}$ & $39.8^{\mathrm{a}, \mathrm{b}, \mathrm{c}, \mathrm{d}}$ \\
\hline $20 \%$ & 2.3 & 2.6 & $0.682 \pm 0.151$ & $1.19 \pm 0.06$ & $48.5 \pm 13.1^{\mathrm{a}, \mathrm{e}}$ & $49.7^{\mathrm{e}}$ \\
\hline $40 \%$ & $2.0^{\mathrm{a}}$ & $3.0^{\mathrm{a}, \mathrm{b}}$ & $0.35 \pm 0.16$ & $1.37 \pm 0.51^{\mathrm{a}}$ & $47.1 \pm 11.7^{\mathrm{f}, \mathrm{g}}$ & $52.3^{\mathrm{a}, \mathrm{f}}$ \\
\hline $60 \%$ & 2.2 & 2.6 & $0.503 \pm 0.17$ & $1.21 \pm 0.42$ & $54.3 \pm 11.0^{\mathrm{b}}$ & $55.2^{\mathrm{b}, \mathrm{g}}$ \\
\hline $80 \%$ & 2.2 & $2.0^{\mathrm{b}}$ & $0.65 \pm 0.28$ & $0.79 \pm 0.14$ & $58.1 \pm 10.7^{\mathrm{c}, \mathrm{e}, \mathrm{f}}$ & $55.8^{\mathrm{c}, \mathrm{h}}$ \\
\hline $100 \%$ & $2.5^{\mathrm{a}}$ & 2.4 & $0.46 \pm 0.09$ & $0.72 \pm 0.31$ & $56.7 \pm 9.7^{\mathrm{d}, \mathrm{g}}$ & $73.2^{\mathrm{d}, \mathrm{e}, \mathrm{f}, \mathrm{g}, \mathrm{h}}$ \\
\hline
\end{tabular}

${ }_{\mathrm{a}, \mathrm{b}, \mathrm{c}}$ Statistically significant differences $(p<0.05)$ between groups; for median, Kruskal-Wallis test; for mean, Tukey test. 
(a)

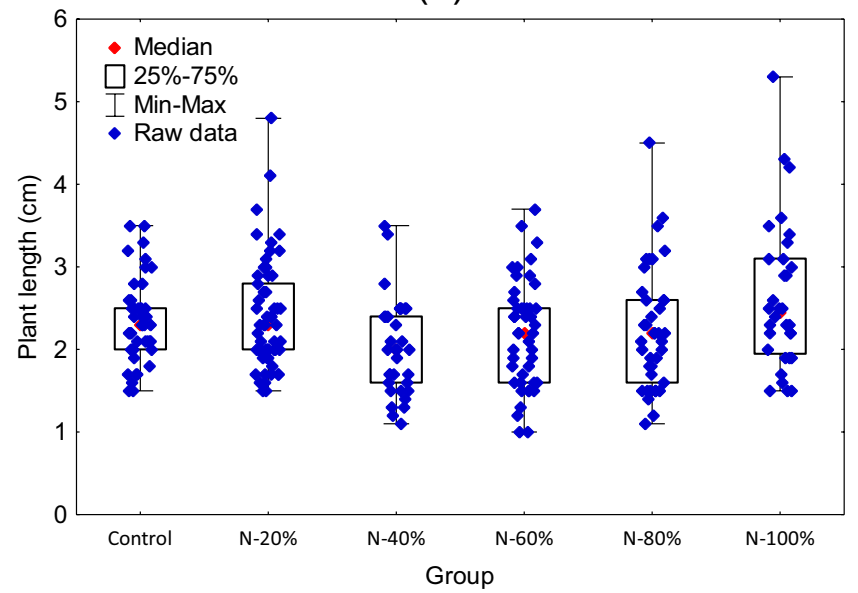

(b)

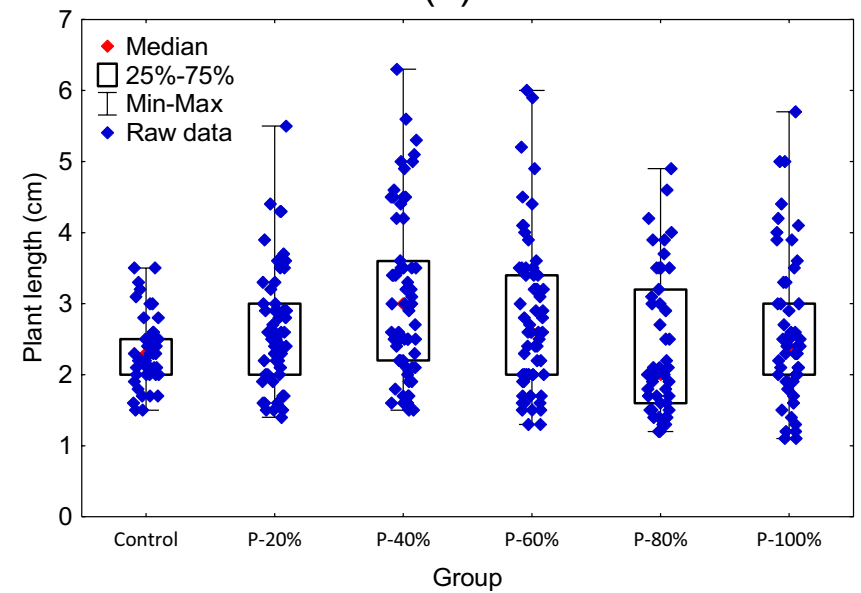

Fig. 2 Effect of different concentrations of algal extract obtained with a Neutrase ${ }^{\circledR}$ and $\mathbf{b}$ Protamex $®$ on the radish seedlings length (cm)

18 and $12 \%$, respectively. Significant stimulation of tomato plant length as compared to the control was also observed by Mzibra et al. (2018) who tested polysaccharide-enriched extracts produced from red seaweeds (Gigartina sp., Schizymenia dubyi, Chondracanthus acicularis, Gelidium crinale, Plocamium cartilagineum, Gracilaria multipartita) applied at a dose of $0.2 \mathrm{mg} / \mathrm{mL}$ [26]. The increase in plant length can be attributed to the action of polysaccharides, which can enhance plant development by regulating metabolic pathways such as photosynthesis, cell division, purine and pyrimidine synthesis, and pathways involved in sulfur and nitrogen assimilation [27, 35].

Effect of enzyme algal extracts on radish seedling fresh weight Figure 3 and Table 2 show the effect of algal extracts on seedling fresh weight. The highest fresh weight of radish was obtained with $40 \%$ Protamex ${ }^{\circledR}$ extract and this difference was statistically significant when compared with the control group. For all concentrations of extract produced with Protamex ${ }^{\circledR}$, the fresh weight was higher than in the control group. In general, it can be seen that the weight of plants decreased with increasing concentration of the extract (Fig. 3b). In the case of Neutrase ${ }^{\circ}$, the plant weight higher than that in the control group was observed for $20 \%$ (higher by $8.8 \%$ ) and $40 \%$ (higher by $4.1 \%$ ). These differences were not statistically significant (Fig. 3a). Finally, Protamex® had a greater impact on the fresh weight of plants than Neutrase ${ }^{\circledR}$. In conclusion, the Protamex ${ }^{\circledR}$ enzyme seemingly extracted more compounds from the seaweed that effect positively plant weight than Neutrase ${ }^{\circledR}$. (a)

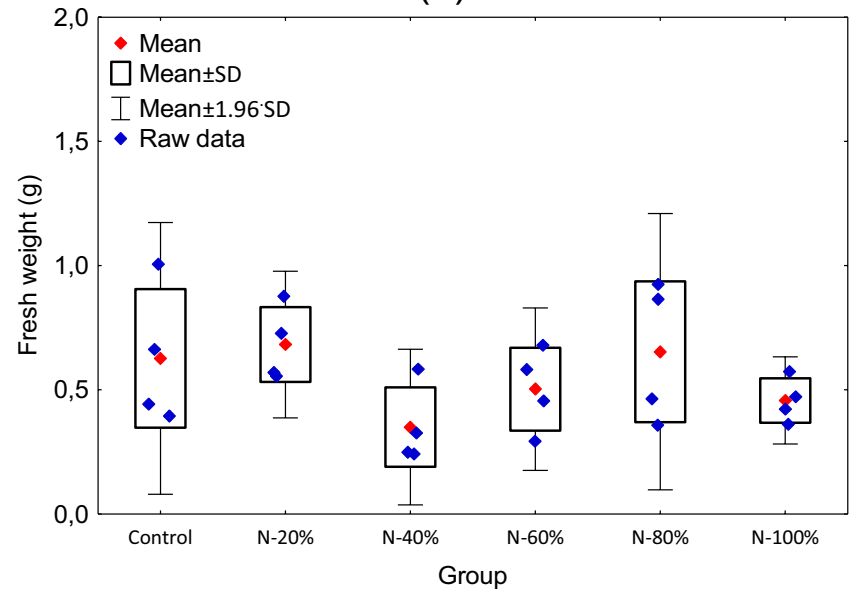

(b)

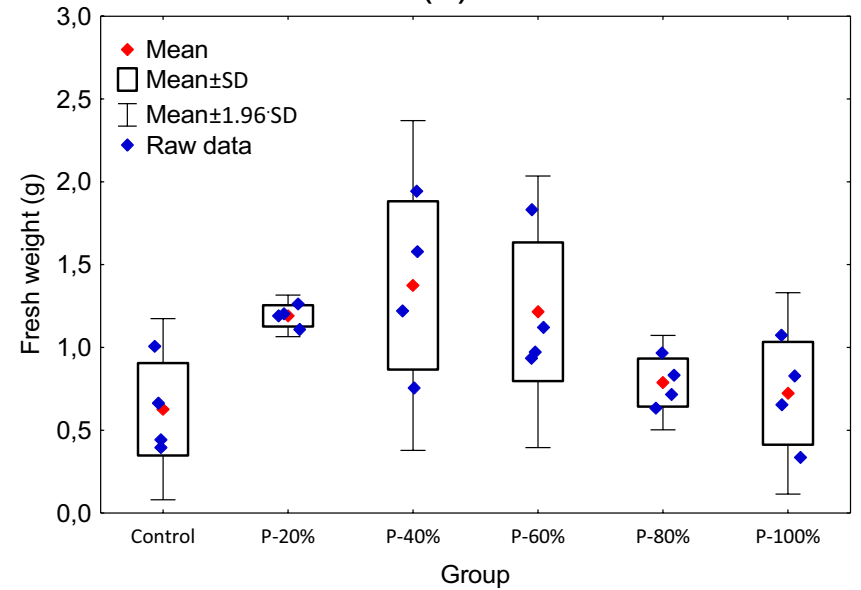

Fig. 3 Effect of different concentrations of algal extract obtained with a Neutrase ${ }^{\circledR}$ and $\mathbf{b}$ Protamex ${ }^{\circledR}$ enzymes on seedling fresh weight (g) $(N=4)$ 
Our results coincide with other similar studies such as that of Rathore et al. (2009), where the effect of extracts from red Kappaphycus alvarezii was tested on various parameters including plant weight. In this experiment, the highest plant weight was achieved for seaweed extract at a concentration of $15 \%$ [36]. Also alkaline extract produced from red seaweed Gelidium robustum applied at a concentration of $2 \%$ showed a significant increase in the fresh weight of mung bean (Vigna radiata) by $43 \%$ as compared to the control group [32]. The increase in plant weight due to the application of seaweed extracts could be explained by the presence of certain growth-promoting factors (such as phytohormones) or of micro- and macronutrients in the extract $[8,32,36]$.

\section{Effect of enzyme algal extracts on the chlorophyll content in} radish seedlings The evaluation of the chlorophyll content in plants is another marker used in this study to assess the effect of enzyme extracts on radish plant growth. The effect of different concentrations of the two enzyme algal extracts on the chlorophyll content (measured by SPAD) of radish seedlings is presented in Fig. 4 and in Table 2.

For all tested concentrations of extract, radish seedlings contained higher content of chlorophyll than the control group (watered with distilled water). Generally, an increase in the chlorophyll content was also observed along with an increase in the concentration of the extract. For Neutrase ${ }^{\circledR}$ extracts, the highest chlorophyll content was achieved for a concentration of $80 \%$ then for $100 \%$ (Fig. 4a), whereas for Protamex ${ }^{\circledR}$ extract, the highest chlorophyll content was achieved with $100 \%$ extract (Fig. 4b). As shown in Table 2, there were many statistically significant differences between the experimental groups and the control group treated with distilled water. As found in our experiments, the application of Solieria chordalis enzyme extracts resulted in an increase in plant chlorophyll content, making this alga a very good candidate as a potential biostimulant of plant growth. Enhanced chlorophyll content in plants can lead to improved plant growth [8]. The improvement of chlorophyll content can also result in the healthier and larger-sized plants than plants in the control group. This was also confirmed in the literature for extracts produced from other red seaweeds [26]. The authors showed that polysaccharide-enriched extracts produced from Gigartina sp., Schizymenia dubyi, Chondracanthus acicularis, Gelidium crinale, Plocamium cartilagineum, and Gracilaria multipartita applied at a dose $0.2 \mathrm{mg} / \mathrm{mL}$ had a significant effect on the chlorophyll $a$ and $b$ biosynthesis in plant leaves as compared to control. In the literature, it was also showed that maize (Zea mays) treated with red seaweeds (Laurencia obtusa, Corallina elongata, and Jania rubens) used as soil additives had a higher content of nitrogen than the control group [37]. Usually, plants with higher nitrogen content have a darker green color and higher chlorophyll content. Chlorophyll content is a very important factor to take into consideration when attempting to achieve higher crop yield and higher quality and quantities of nutrients present in plants destined for consumption. The entire process of photosynthesis is dependent on chlorophyll, as this pigment is highly involved in the transformation of light energy into organic matter. Therefore, by tracking its content in plants, we can evaluate the efficiency of photosynthesis.

Taking into account the results obtained from germination tests (number of germinated seeds, plant length, fresh weight, chlorophyll content), $40 \%$ extract obtained from Solieria chordalis with Protamex ${ }^{\circledR}$ or $20 \%$ extract obtained with Neutrase $®$ are recommended for further research — pot experiments in a greenhouse. The application of enzyme extracts from red seaweeds with biostimulant properties can (a)

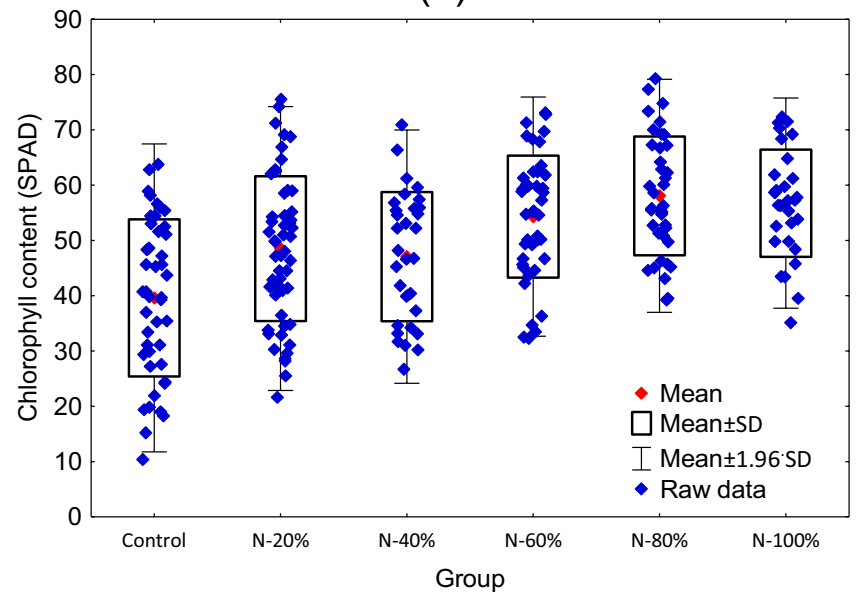

(b)

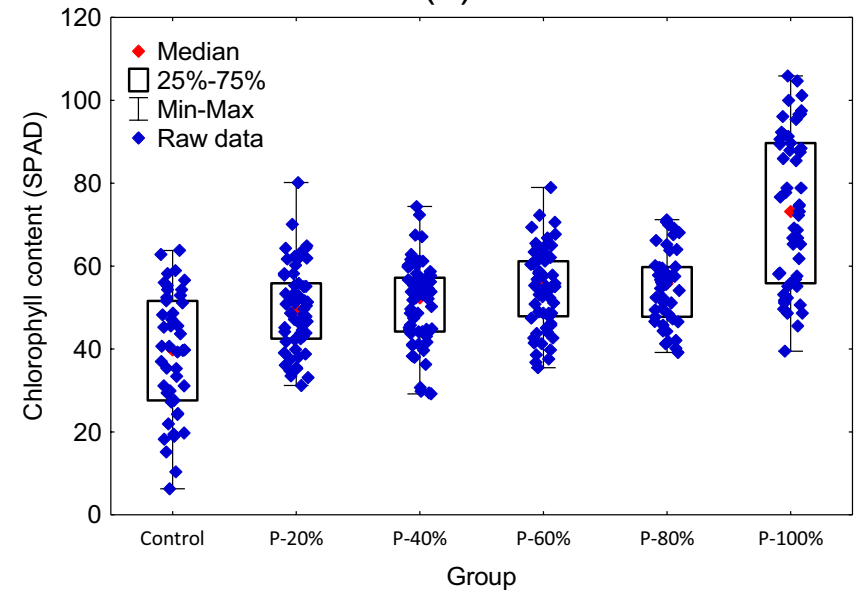

Fig. 4 Effect of different concentrations of algal extract obtained with a Neutrase ${ }^{\circledR}$ and $\mathbf{b}$ Protamex ${ }^{\circledR}$ on the chlorophyll content in radish seedlings 
be a promising step towards a more sustainable agriculture and could contribute to the reduction of current mineral fertilizers and plant protection products.

\subsection{Biosorption properties}

In this manuscript, the post-extraction residue, as well as the raw Solieria chordalis biomass, were evaluated as potential sorbents in wastewater treatment or as carriers of metal ions for fertilization purposes. Therefore, their biosorption properties were examined. These materials have not been studied as biosorbents of metal ions so far. In the literature, the biomass of red seaweeds is mainly studied as a low-cost biosorbent for the removal of heavy metal ions from aqueous solutions, for example Palmaria palmata and Polysiphonia lanosa as sorbents of $\mathrm{Cr}(\mathrm{III})$ and $\mathrm{Cr}(\mathrm{VI})$ ions [28]; Pterocladia capillacea [30] as a sorbent of $\mathrm{Cr}(\mathrm{III})$ ions; Chondracanthus chamissoi as a sorbent of $\mathrm{Cd}(\mathrm{II})$ and $\mathrm{Pb}$ (II) ions [29]; Kappaphycus sp. as a sorbent of $\mathrm{Zn}(\mathrm{II}), \mathrm{Cu}(\mathrm{II})$, $\mathrm{Fe}(\mathrm{II})$, and $\mathrm{Pb}(\mathrm{II})$ ions [31]; and Corallina mediterranea, Galaxaura oblongata, Jania rubens, and Pterocladia capillacea as sorbents of $\mathrm{Co}(\mathrm{II}), \mathrm{Cd}(\mathrm{II}), \mathrm{Cr}(\mathrm{III})$, and $\mathrm{Pb}(\mathrm{II})$ ions [38]. In the present paper, preliminary experiments were performed on $\mathrm{Cr}$ (III) ions, due to the simple analytical method for determining their concentration in solution. The sorption experiments were essentially kinetics studies, evaluation of the time needed to reach equilibrium, calculation of the biosorption capacity of biosorbents towards metal ions at equilibrium and equilibrium studies, and determination of maximum biosorption capacity and affinity of seaweeds binding sites for the metal ions.

\subsubsection{Kinetic studies of biosorption}

The effect of $\mathrm{pH}$ (4 and 5), initial concentration of metal ions in the solution $\left(C_{0} 100,200,300,400 \mathrm{mg} / \mathrm{L}\right)$, and biosorbent content in the solution $\left(C_{\mathrm{S}} 1\right.$ and $\left.2 \mathrm{~g} / \mathrm{L}\right)$ on the biosorption properties of tested algal sorbents is presented in Table 2 and Fig. 5 for pH, Fig. 6 for $C_{0}$, and Fig. 7 for $C_{\mathrm{S}}$. Table 3 summarizes the parameters of the pseudo-second-order model for biosorption of $\mathrm{Cr}(\mathrm{III})$ ions by tested biosorbents performed in different experimental conditions described above. The data showed good compliance with the pseudo-secondorder model for examined parameters $-R^{2}$ values were all higher than 0.9 .

When comparing the biosorption capacity of raw Solieria chordalis with the post-extraction residues, it is clear that the use of raw biomass gave on average a higher $q_{\mathrm{eq}}$ than the use of post-extraction residues, for the same experimental conditions. The highest $q_{\mathrm{eq}}, 55.6 \mathrm{mg} / \mathrm{g}$ reached during these experiments, was for $\mathrm{pH} 5, C_{\mathrm{s}} 2 \mathrm{~g} / \mathrm{L}$, and $C_{0} 300 \mathrm{mg} / \mathrm{L}$ with raw biomass as a biosorbent.

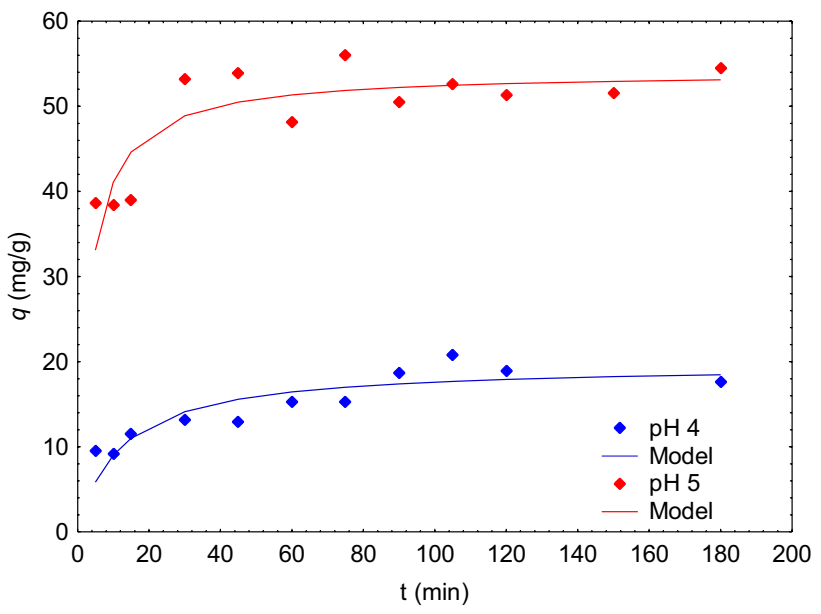

Fig. 5 The effect of $\mathrm{pH}$ on biosorption capacity of Solieria chordalis towards $\mathrm{Cr}(\mathrm{III})$ ions $\left(C_{0} 300 \mathrm{mg} / \mathrm{L}, C_{\mathrm{S}} 1 \mathrm{~g} / \mathrm{L}\right)$

Effect of $\mathrm{pH}$ on the biosorption capacity The effect of $\mathrm{pH}$ (pH 4 and $5, C_{0} 300 \mathrm{mg} / \mathrm{L}, C_{\mathrm{S}} 1 \mathrm{~g} / \mathrm{L}$ ) on the biosorption capacity of Solieria chordalis towards $\mathrm{Cr}(\mathrm{III})$ ions is presented in Fig. 5.

Since $\mathrm{Cr}(\mathrm{III})$ is cationic in solution $\left(\mathrm{Cr}^{3+}\right.$ and $\left.\mathrm{CrOH}_{2}^{+}\right)$, the $\mathrm{pH}$ has a significant effect on the binding behavior of chromium species [28]. The biosorption experiments were not performed above $\mathrm{pH} 5$, because at a $\mathrm{pH}$ higher than 5.5, chromium ions precipitate as $\mathrm{Cr}(\mathrm{OH})_{3}$ [39]. The biosorption capacity at $\mathrm{pH} 5$ for Solieria chordalis was almost three times higher than that at $\mathrm{pH} 4$; therefore, $\mathrm{pH} 5$ was used in further experiments. The same $\mathrm{pH}$ was chosen for the sorption not only $\mathrm{Cr}(\mathrm{III})$ ions, but also $\mathrm{Co}(\mathrm{II}), \mathrm{Cd}(\mathrm{II})$, and $\mathrm{Pb}$ (II) ions by other red seaweeds-Corallina mediterranea, Galaxaura oblongata, Jania rubens, and Pterocladia capillacea in the work of Ibrahim (2011) [38]. At lower pH, more protons are present in the solution and they compete with metal ions for the active sites present on the algal surface and bind with the functional groups. As a result, less active sites are available for the exclusive uptake of metal ions, and therefore the biosorption capacity of the metal ions is reduced $[31,38,39]$. On the other hand, as $\mathrm{pH}$ increases, the concentration of protons decreases and there is less competition for the metal ions to bind with active sites. As a result, more functional groups (and consequently more binding sites) become exposed. The biosorption capacity is therefore substantially increased with the increase in $\mathrm{pH}[38,39]$.

Figure 5 also presents that the equilibrium of biosorption was attained within 90-120 min, showing a rapid initial biosorption. These results coincide with literature data for other red seaweeds such as Kappaphycus sp., where the time required to reach the equilibrium for the sorption of $\mathrm{Zn}(\mathrm{II}), \mathrm{Cu}(\mathrm{II})$, $\mathrm{Pb}$ (II), and $\mathrm{Fe}$ (II) ions was 90-120 min [31]. However, this time was even shorter for other red seaweed species; for example, 
for the sorption of $\mathrm{Cr}(\mathrm{VI})$ ions by Pterocladia capillacea, it was $60 \mathrm{~min}$ [30], the same for the sorption of $\mathrm{Co}(\mathrm{II}), \mathrm{Cd}(\mathrm{II})$, $\mathrm{Cr}(\mathrm{III})$, and $\mathrm{Pb}$ (II) ions by Corallina mediterranea, Galaxaura oblongata, Jania rubens, and Pterocladia capillacea [38], and for the sorption of Cr(III) ions by Palmaria palmata and Polysiphonia lanosa it was only $30 \mathrm{~min}$ [28].

\section{Effect of initial concentration of metal ions in the solution} on the biosorption capacity The effect of initial concentration of metal ions in the solution $C_{0}(100,200,300$, and $400 \mathrm{mg} / \mathrm{L}, \mathrm{pH} 5, C_{\mathrm{S}} 1 \mathrm{~g} / \mathrm{L}$ ) on biosorption capacity of Solieria chordalis, as well as post-extraction residues obtained with Neutrase ${ }^{\circledR}$ and Protamex ${ }^{\circledR}$, is shown in Table 3 and Fig. 6.

For the raw biomass, the quantity of adsorbed metal ions per gram of alga at equilibrium was the highest for $C_{0}$ $300 \mathrm{mg} / \mathrm{L}$ with $q_{\mathrm{eq}} 54.1 \mathrm{mg} / \mathrm{g}$. The biosorption capacity was higher when $C_{0}$ was $300 \mathrm{mg} / \mathrm{L}$ as compared to $C_{0}$ equal to
$400 \mathrm{mg} / \mathrm{L}$ (Fig. 6a). This may be because at higher initial concentrations in metal ions, the binding sites available for biosorption become more rapidly saturated, therefore limiting the diffusion of the ions into the boundary layer of the algae [40]. This phenomenon was also observed for the biosorption of $\mathrm{Zn}$ (II), $\mathrm{Cu}(\mathrm{II}), \mathrm{Pb}(\mathrm{II})$, and $\mathrm{Fe}$ (II) ions by the red seaweed Kappaphycus sp. for the initial concentration range $25-200 \mathrm{mg} / \mathrm{L}$ [31]. In the case of both post-extraction residues, the highest $q_{\mathrm{eq}}$ was obtained for $C_{0} 200 \mathrm{mg} / \mathrm{L}-$ $48.8 \mathrm{mg} / \mathrm{g}$ for Neutrase ${ }^{\circledR}$ (Fig. 6b) and $43.3 \mathrm{mg} / \mathrm{g}$ for Protamex ${ }^{\circledR}$ (Fig. 6c). For nearly all of the groups tested, $q_{\text {eq }}$ was at its lowest for $C_{0} 400 \mathrm{mg} / \mathrm{L}$.

The effect of biosorbent content in the solution on the biosorption capacity The impact of the biosorbent content $\left(C_{\mathrm{S}}\right)$ in the solution on the biosorption capacity was analyzed for two different concentrations -1 and $2 \mathrm{~g} / \mathrm{L}\left(C_{0} 300 \mathrm{mg} / \mathrm{L}\right.$ and $\mathrm{pH}$ 5). The results are shown in Table 3 and Fig. 7. (a)

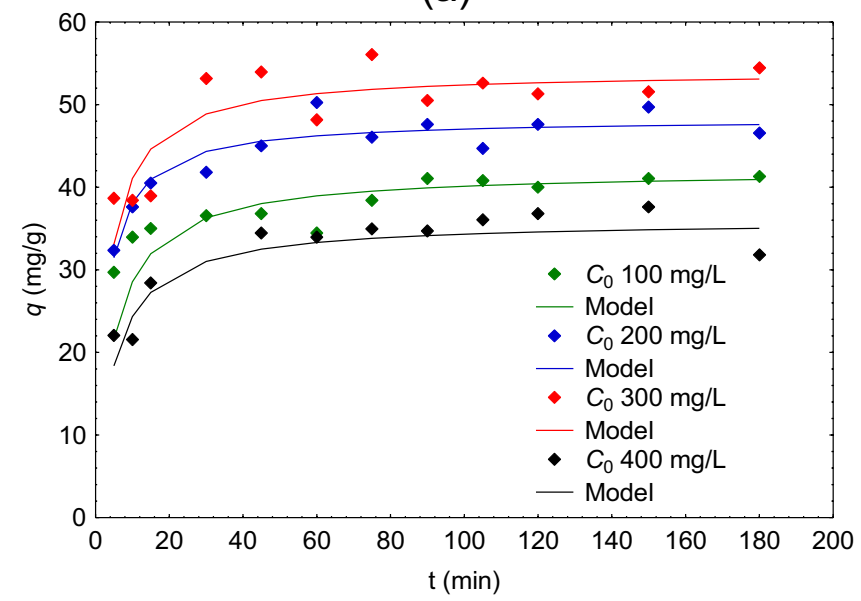

(b)

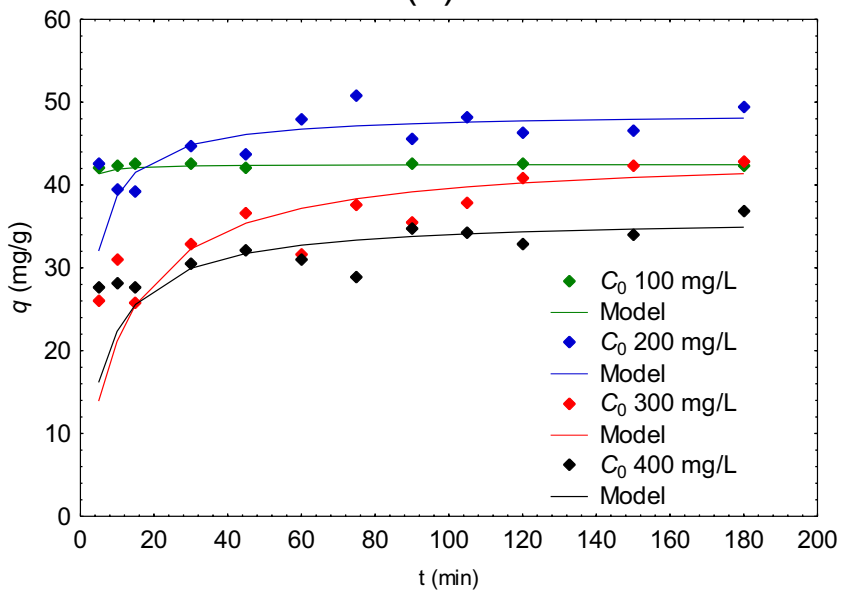

(c)

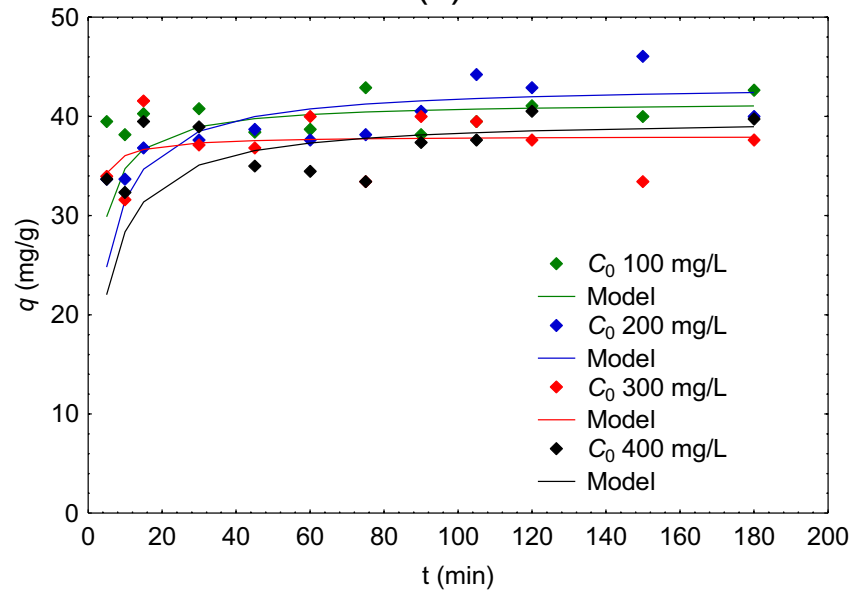

Fig. 6 Effect of $C_{0}$ on biosorption capacity of $\mathbf{a}$ Solieria chordalis, $\mathbf{b}$ post-extraction residue obtained with Neutrase ${ }^{\circ}$, c post-extraction residue obtained with Protamex ${ }^{\circledR}\left(\mathrm{pH} 5, C_{\mathrm{S}} 1 \mathrm{~g} / \mathrm{L}\right)$ 
(a)

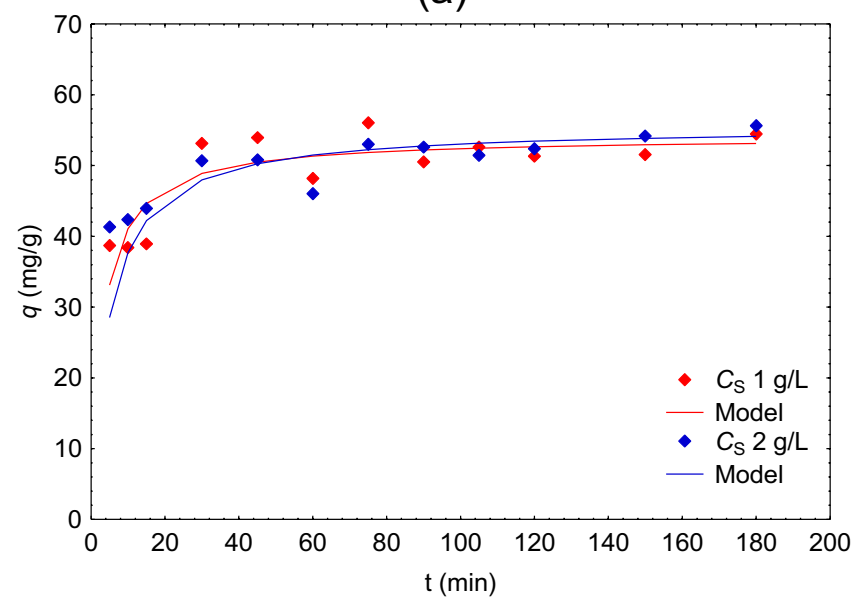

(b)

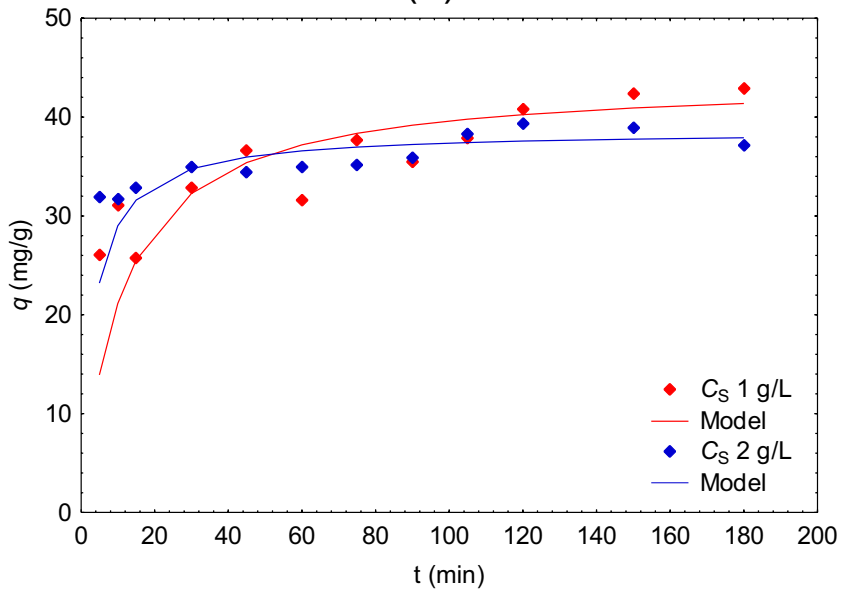

(c)

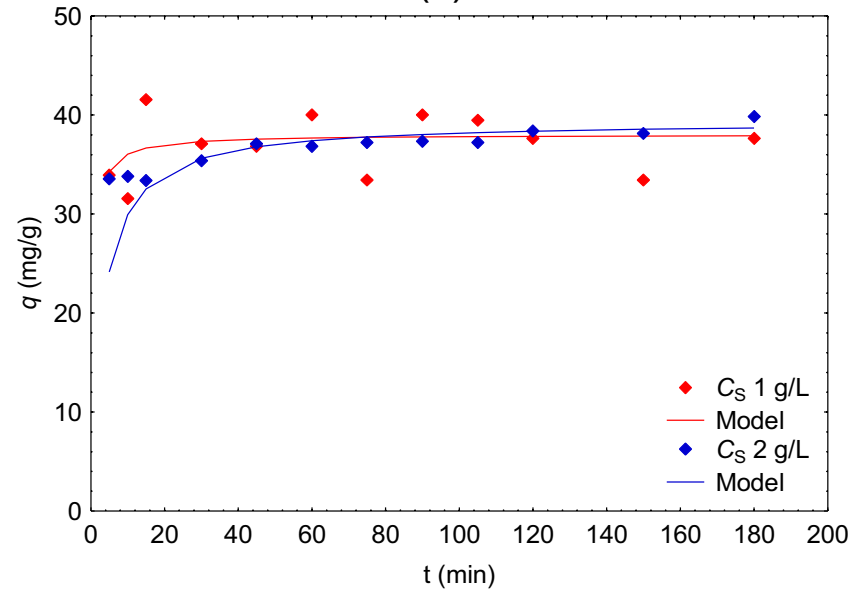

Fig. 7 The effect of $C_{\mathrm{S}}$ on biosorption capacity of a Solieria chordalis, b post-extraction residue obtained with Neutrase ${ }^{\circledR}$, $\mathbf{c}$ post-extraction residue obtained with Protamex ${ }^{\circledR}\left(\mathrm{pH} 5, C_{0} 300 \mathrm{mg} / \mathrm{L}\right)$

For Solieria chordalis and the two post-extraction residues, the biosorption capacity was very similar for both tested sorbent concentrations. The biosorbent content did not have a major effect on the biosorption capacity of the alga. However, as was shown in the literature, the biomass dosage can have an effect on the biosorption of heavy metal ions. Ibrahim (2011) showed that for the sorption of Co(II), $\mathrm{Cd}(\mathrm{II}), \mathrm{Cr}(\mathrm{III})$, and $\mathrm{Pb}(\mathrm{II})$ ions by the red seaweeds Corallina mediterranea, Galaxaura oblongata, Jania rubens, and Pterocladia capillacea, the biosorption capacity increased with the increase in biomass concentration in the solution from 1 to $10 \mathrm{~g} / \mathrm{L}(1,2,5$, and $10 \mathrm{~g} / \mathrm{L})$ and later was constant until $C_{\mathrm{S}} 40 \mathrm{~g} / \mathrm{L}$ [38]. The higher dose of biosorbent in the solution could provide a greater availability of exchangeable sites for the sorbed metal ions.

Equilibrium of biosorption The results of the experiments on biosorption equilibrium can be described by several isotherms, for example Langmuir, Freundlich, and
Dubinin-Radushkevich [4, 30, 31, 40, 41]. However, the Langmuir equation is the most often used. Biosorption isotherms for Solieria chordalis and Neutrase ${ }^{\circledR}$ and Protamex ${ }^{\circledR}$ post-extraction residues are shown in Fig. 8.

The parameters of Langmuir isotherm $\left(q_{\max }\right.$ and $\left.b\right)$ were determined via linearization of Eq. 4. For Solieria chordalis, $q_{\max }$ was $48.1 \mathrm{mg} / \mathrm{g}, b 0.113 \mathrm{~L} / \mathrm{mg}$, and $R^{2} 0.999$; for the post-extraction residue obtained with Neutrase ${ }^{\circledR} q_{\max }$ $50.5 \mathrm{mg} / \mathrm{g}, b 0.850 \mathrm{~L} / \mathrm{mg}$, and $R^{2} 0.991$; and for the postextraction residue obtained with Protamex ${ }^{\circledR} q_{\max } 47.6 \mathrm{mg} / \mathrm{g}$, $b 0.397 \mathrm{~L} / \mathrm{mg}$, and $R^{2} 0.991$. The values of maximum biosorption capacity are comparable for all tested biosorbents. The highest affinity parameter $b$ was obtained for the post-extraction residue obtained with Neutrase $\AA$; therefore, this sorbent had the highest affinity for $\mathrm{Cr}$ (III) ions. The high $R^{2}$ values for all sorbents indicated that the equilibrium data fitted well to the Langmuir model. Dziergowska et al. (2021) also compared biosorption properties of macroalga Cladophora glomerata and post-extraction residue obtained 
Table 3 Parameters of the pseudo-second order model for biosorption of $\mathrm{Cr}$ (III) ions by tested biosorbents

\begin{tabular}{|c|c|c|c|c|}
\hline Biosorbent & Parameter & $q_{\mathrm{eq} 2}(\mathrm{mg} / \mathrm{g})$ & $k_{2}(\mathrm{~g} / \mathrm{mg} \cdot \mathrm{min})$ & $R^{2}$ \\
\hline \multirow[t]{11}{*}{ Solieria chordalis } & \multicolumn{4}{|c|}{$\mathrm{pH}\left(C_{0} 300 \mathrm{mg} / \mathrm{L}, C_{\mathrm{S}} 1 \mathrm{~g} / \mathrm{L}\right)$} \\
\hline & 4 & 19.7 & 0.00430 & 0.973 \\
\hline & 5 & 54.1 & 0.00505 & 0.996 \\
\hline & \multicolumn{4}{|c|}{$C_{\mathrm{s}}(\mathrm{g} / \mathrm{L})\left(C_{0} 300 \mathrm{mg} / \mathrm{L}, \mathrm{pH} 5\right)$} \\
\hline & 1 & 54.1 & 0.00585 & 0.996 \\
\hline & 2 & 55.6 & 0.00380 & 0.997 \\
\hline & \multicolumn{4}{|c|}{$C_{0}(\mathrm{mg} / \mathrm{L})\left(\mathrm{pH} 5, C_{\mathrm{S}} 1 \mathrm{~g} / \mathrm{L}\right)$} \\
\hline & 100 & 42.0 & 0.00505 & 0.997 \\
\hline & 200 & 48.3 & 0.00773 & 0.996 \\
\hline & 300 & 54.1 & 0.00505 & 0.996 \\
\hline & 400 & 36.0 & 0.00581 & 0.978 \\
\hline \multirow[t]{8}{*}{ Neutrase $®$ post-extraction residue } & \multicolumn{4}{|c|}{$C_{\mathrm{S}}(\mathrm{g} / \mathrm{L})\left(C_{0} 300 \mathrm{mg} / \mathrm{L}, \mathrm{pH} 5\right)$} \\
\hline & 1 & 43.9 & 0.00212 & 0.987 \\
\hline & 2 & 38.6 & 0.00781 & 0.997 \\
\hline & \multicolumn{4}{|c|}{$C_{0}(\mathrm{mg} / \mathrm{L})\left(\mathrm{pH} 5, C_{\mathrm{S}} 1 \mathrm{~g} / \mathrm{L}\right)$} \\
\hline & 100 & 42.5 & 0.170 & 0.999 \\
\hline & 200 & 48.8 & 0.00780 & 0.997 \\
\hline & 300 & 43.9 & 0.00212 & 0.987 \\
\hline & 400 & 36.1 & 0.00450 & 0.990 \\
\hline \multirow[t]{8}{*}{ Protamex ${ }^{\circledR}$ post-extraction residue } & \multicolumn{4}{|c|}{$C_{\mathrm{s}}(\mathrm{g} / \mathrm{L})\left(C_{0} 300 \mathrm{mg} / \mathrm{L}, \mathrm{pH} 5\right)$} \\
\hline & 1 & 38.0 & 0.0480 & 0.995 \\
\hline & 2 & 39.4 & 0.00806 & 0.998 \\
\hline & \multicolumn{4}{|c|}{$C_{0}(\mathrm{mg} / \mathrm{L})\left(\mathrm{pH} 5, C_{\mathrm{S}} 1 \mathrm{~g} / \mathrm{L}\right)$} \\
\hline & 100 & 41.5 & 0.0124 & 0.996 \\
\hline & 200 & 43.3 & 0.00620 & 0.989 \\
\hline & 300 & 38.0 & 0.0480 & 0.995 \\
\hline & 400 & 39.8 & 0.00620 & 0.992 \\
\hline
\end{tabular}

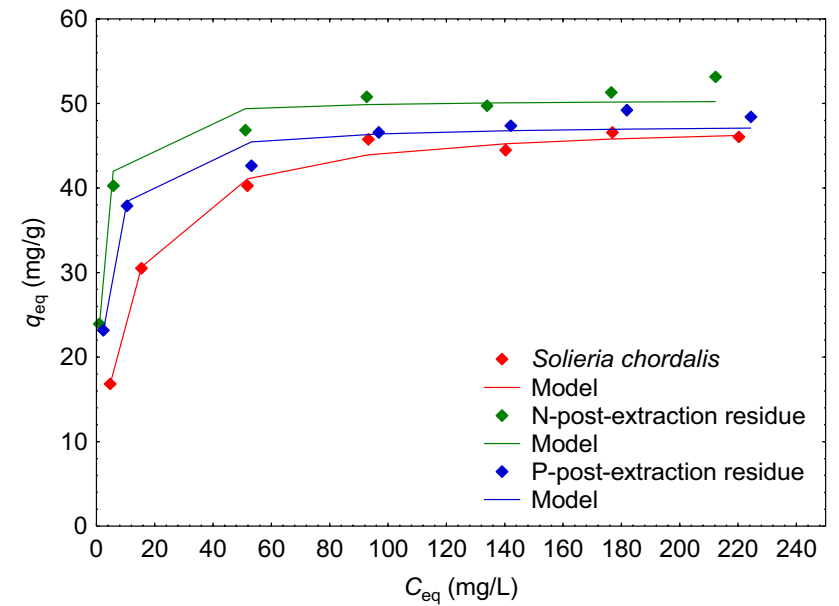

Fig. 8 Langmuir isotherms carried out for biosorption of $\mathrm{Cr}$ (III) ions by Solieria chordalis (raw biomass) and Neutrase ${ }^{\circledR}(\mathrm{N})$ and Protamex® $(\mathrm{P})$ post-extraction residues $\left(\mathrm{pH} 5, C_{\mathrm{S}} 1 \mathrm{~g} / \mathrm{L}, C_{0} 25-300 \mathrm{mg} / \mathrm{L}\right)$

after ultrasound-assisted extraction of this biomass towards $\mathrm{Cr}$ (III) ions. The maximum biosorption capacity of the residue was higher, $192 \mathrm{mg} / \mathrm{g}$, than for raw biomass, $169 \mathrm{mg} / \mathrm{g}$, indicating that it can be successfully used for removal of heavy metal ions from wastewater [4].

In the literature, there are several studies dealing with biosorption of metal ions by different species of red seaweeds, but results concerning biosorption properties of Solieria chordalis are missing (Table 4). Other red seaweeds represented smaller biosorption capacity towards $\mathrm{Cr}(\mathrm{III})$ ions than Solieria chordalis, but for the comparison, all experimental conditions should be taken into account. For example, $q_{\mathrm{eq}}$ of Solieria chordalis towards $\mathrm{Cr}(\mathrm{III})$ was $55.6 \mathrm{mg} / \mathrm{g}\left(\mathrm{pH} 5, C_{\mathrm{S}} 2 \mathrm{~g} / \mathrm{L}, C_{0} 300 \mathrm{mg} / \mathrm{L}\right)$ and $q_{\max }$ of Palmaria palmata, $29.6 \mathrm{mg} / \mathrm{g}$, and Polysiphonia lanosa, $33.8 \mathrm{mg} / \mathrm{g}$, for similar experimental conditions.

\subsubsection{FTIR analysis}

Fourier transform infrared analysis is important in the biosorption studies because it reveals the interactions of functional groups (e.g., amino, carboxyl, sulfonate, and hydroxyl) on the surface of biosorbents with metal ions in the solution [28, 30, 31, 41]. FTIR spectroscopy allows to detect 
vibrational frequency changes in seaweeds and to identify functional groups capable of interacting with metal ions [28].

The FTIR spectra of natural and enriched with $\mathrm{Cr}(\mathrm{III})$ ions tested biosorbent Solieria chordalis post-extraction residue obtained with Neutrase ${ }^{\circledR}$ and with Protamex ${ }^{\circledR}$ (Fig. 9) consist of a large number of transmittance peaks which indicate the complex nature of the biomass. The spectra are globally similar to those observed in the literature for Solieria chordalis biomass [15], and no major differences were observed between samples before and after biosorption with $\mathrm{Cr}(\mathrm{III})$. Spectrum shows some typical large strong bands between 3400 and $3200 \mathrm{~cm}^{-1}$ corresponding to the stretching of O-H linkage (water, carbohydrates), at $1640-1620 \mathrm{~cm}^{-1}$ to the stretching of N-H linkage of amine, at $1260-1210 \mathrm{~cm}^{-1}$ of stretching of $\mathrm{S}=\mathrm{O}$ of sulfate groups, at $846 \mathrm{~cm}^{-1}$ for galactose-4-sulfate, at 930 and $804 \mathrm{~cm}^{-1}$ for 3,6-anhydrogalactose-2-sulfate from carrageenan, and at $750 \mathrm{~cm}^{-1}$ for $\mathrm{C}-\mathrm{H}$ linkages of carbohydrates [15]. The difference of band intensity came from the amount of sample used for analysis.

\section{Conclusions}

The aim of this study was to test the seaweed Solieria chordalis and extracts of Solieria chordalis for potential biostimulant and biosorbent properties. Enzyme-assisted extraction proved to be an efficient, rapid extraction method and is therefore a good candidate for future applications. Solieria chordalis extracts, especially at lower concentrations ranging from 20 to $40 \%$, were found to be effective biostimulants of plant growth as their application on seeds increased the height, weight, and chlorophyll content of the seedlings. For future experiments, the effectiveness of enzyme algal extracts should be confirmed in pot experiments and field trials. Additionally, different application methods of extracts (for example foliar, soil application, or soaking of the seeds) can be tested. In terms of biosorbent properties, Solieria

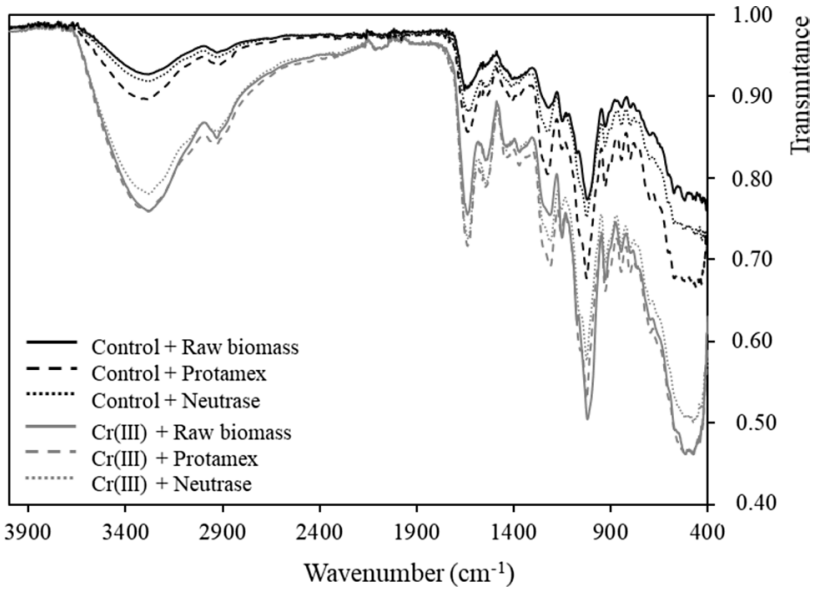

Fig. 9 Raw FTIR spectrum of raw biomass (full line), Protamex ${ }^{\circledR}$ residue (dashed line), and Neutrase ${ }^{\circledR}$ residue (dotted line) for the control (black) and after biosorption of $\mathrm{Cr}$ (III) (gray), on the range 4000 to $400 \mathrm{~cm}^{-1}$

chordalis and its post-extraction residues were all capable of adsorbing $\mathrm{Cr}(\mathrm{III})$ ions. The biosorption capacity was influenced by different experimental parameters such as $\mathrm{pH}$, biosorbent concentration, and initial metal ion concentration. The highest biosorption capacity $q_{\mathrm{eq}}, 55.6 \mathrm{mg} / \mathrm{g}$, was reached for Solieria chordalis for $\mathrm{pH} 5, C \mathrm{~s} 2 \mathrm{~g} / \mathrm{L}$, and $C_{0} 300 \mathrm{mg} / \mathrm{L}$.

Through this study, we highlighted remarkably interesting properties of the red macrolga Solieria chordalis. Instead of being removed from the beaches and destroyed, this currently unexploited biomass could now be used to produce biostimulants of plant/crop growth, and biosorbents of, for example, toxic metals in polluted waters/soil. Using seaweed for both these applications has tremendous advantages and relevance when considering the environmental and economic crisis that we are currently in. Not only is seaweed a cost-efficient resource; it is also abundantly available, and can be exploited using highly eco-friendly treatment methods such as enzymeassisted extraction, as shown in this study.
Table 4 Comparison of biosorption properties of different red seaweed species

\begin{tabular}{|c|c|c|c|}
\hline Seaweed species & $q_{\max }(\mathrm{mg} / \mathrm{g})$ & Ion & Parameters \\
\hline Palmaria palmata & 29.6 & $\mathrm{Cr}(\mathrm{III})$ & $\mathrm{pH} 4.5, C_{\mathrm{S}} 2 \mathrm{~g} / \mathrm{L}, C_{0} 25-250 \mathrm{mg} / \mathrm{L}[28]$ \\
\hline Polysiphonia lanosa & 33.8 & $\operatorname{Cr}(\mathrm{III})$ & $\mathrm{pH} 4.5, C_{\mathrm{S}} 2 \mathrm{~g} / \mathrm{L}, C_{0} 25-250 \mathrm{mg} / \mathrm{L}[28]$ \\
\hline Jania rubens & 28.5 & $\mathrm{Cr}(\mathrm{III})$ & $\mathrm{pH} 5, C_{\mathrm{S}} 10 \mathrm{~g} / \mathrm{L}, C_{0} 25-300 \mathrm{mg} / \mathrm{L}[38]$ \\
\hline Ptredocladia capillacea & 34.7 & $\mathrm{Cr}(\mathrm{III})$ & $\mathrm{pH} 5, C_{\mathrm{S}} 10 \mathrm{~g} / \mathrm{L}, C_{0} 25-300 \mathrm{mg} / \mathrm{L}[38]$ \\
\hline Corallina mediterranea & 70.3 & $\mathrm{Cr}(\mathrm{III})$ & $\mathrm{pH} 5, C_{\mathrm{S}} 10 \mathrm{~g} / \mathrm{L}, C_{0} 25-300 \mathrm{mg} / \mathrm{L}[38]$ \\
\hline Galaxaura oblongata & 105.2 & $\mathrm{Cr}(\mathrm{III})$ & $\mathrm{pH} 5, C_{\mathrm{S}} 10 \mathrm{~g} / \mathrm{L}, C_{0} 25-300 \mathrm{mg} / \mathrm{L}[38]$ \\
\hline Pterocladia capillacea & 12.9 & $\mathrm{Cr}(\mathrm{VI})$ & $\mathrm{pH} 1, C_{\mathrm{S}} 10 \mathrm{~g} / \mathrm{L}, C_{0} 5-125 \mathrm{mg} / \mathrm{L}[30]$ \\
\hline Kappaphycus sp. & $\begin{array}{l}16.2 \\
19.5 \\
16.9 \\
22.2\end{array}$ & $\begin{array}{l}\mathrm{Zn}(\mathrm{II}) \\
\mathrm{Cu}(\mathrm{II}) \\
\mathrm{Fe}(\mathrm{II}) \\
\mathrm{Pb}(\mathrm{II})\end{array}$ & $\mathrm{pH} 5, C_{\mathrm{S}} 4 \mathrm{~g} / \mathrm{L}, C_{0} 25-200 \mathrm{mg} / \mathrm{L}[31]$ \\
\hline Solieria chordalis & 48.1 & $\mathrm{Cr}(\mathrm{III})$ & $\mathrm{pH} 5, C_{\mathrm{S}} 1 \mathrm{~g} / \mathrm{L}, C_{0} 25-300 \mathrm{mg} / \mathrm{L}$ Present study \\
\hline
\end{tabular}


Acknowledgements This work was performed in the framework of a grant entitled: "Eco-friendly technologies for the management of seaweed biomass for products useful for sustainable agriculture and biosorbents used for the removal of heavy metal ions from the environment" (No 2019/33/B/NZ9/01844) from the National Science Centre in Poland.

Author contribution Olivia Spain: investigation; formal analysis; software; writing — original draft; writing — review and editing.

Kevin Hardouin: investigation, formal analysis, methodology, software, visualization, supervision, writing - review and editing.

Nathalie Bourgougnon: conceptualization, methodology, resources, formal analysis, supervision, writing-review and editing.

Izabela Michalak: conceptualization; methodology; resources; software; visualization; writing — original draft; writing — review and editing; formal analysis; funding acquisition; project administration; supervision.

No conflicts, informed consent, human or animal rights applicable.

\section{Declarations}

Competing interests The authors declare no competing interests.

Open Access This article is licensed under a Creative Commons Attribution 4.0 International License, which permits use, sharing, adaptation, distribution and reproduction in any medium or format, as long as you give appropriate credit to the original author(s) and the source, provide a link to the Creative Commons licence, and indicate if changes were made. The images or other third party material in this article are included in the article's Creative Commons licence, unless indicated otherwise in a credit line to the material. If material is not included in the article's Creative Commons licence and your intended use is not permitted by statutory regulation or exceeds the permitted use, you will need to obtain permission directly from the copyright holder. To view a copy of this licence, visit http://creativecommons.org/licenses/by/4.0/.

\section{References}

1. Alves LR, Dos Reis AR, Gratão PL (2016) Heavy metals in agricultural soils: from plants to our daily life. Científica 44(3):346-361

2. Chandini RK, Kumar R, Prakash O (2019) The impact of chemical fertilizers on our

3. Bulgariu L (2020) Efficient use of algae biomass loaded with essential metal ions in the manufacture of feed additives. J Appl Phycol 32:1779-1788

4. Dziergowska K, Wełna M, Szymczycha-Madeja A, Chęcmanowski J, Michalak I (2021) Valorization of Cladophora glomerata biomass and obtained bioproducts into biostimulants of plant growth and as sorbents (biosorbents) of metal ions. Molecules 26:6917

5. Skrzypczak D, Ligas B, Mikula K, Witek-Krowiak A, Samoraj M, Moustakas K, Chojnacka K (2021) Valorization of postextraction biomass residues as carriers of bioavailable micronutrients for plants and livestock. Biomass Conv Bioref 11:3037-3052

6. Khan W, Menon U, Subramanian S, Jithesh M, Rayorath P, Hodges DM, Critchley AT, Craigie J, Norrie J, Prithiviraj B (2009) Seaweed extracts as biostimulants of plant growth and development. J Plant Growth Regul 28:386-399

7. Craigie JS (2015) Seaweed extract stimuli in plant science and agriculture. J Appl Phycol 23:371-393
8. Ali O, Ramsubhag A, Jayaraman J (2021) Biostimulant properties of seaweed extracts in plants: Implications towards sustainable crop production. Plants 10:531

9. Gupta V, Kumar M, Brahmbhatt H, Reddy CRK, Seth A, Jha B (2011) Simultaneous determination of different endogenetic plant growth regulators in common green seaweeds using dispersive liquid-liquid microextraction method. Plant Physiol Biochem 49(11):1259-1263

10. Stiger-Pouvreau V, Thouzeau G (2015) Marine species introduced on the French Channel-Atlantic Coasts: a review of main biological invasions and impacts. Open J Ecol 5:227-257

11. Burlot A-S (2016) Étude de la macroalgue rouge Solieria chordalis: aspects écophysiologiques, production d'extraits et perspectives d'applications. Université Bretagne Sud, France (in French)

12. Neveu T (2016) Les échouages d'algues dans le Morbihan: quelles modalités de gestion et de valorisation? Mémoire master 2. Université de Bretagne Sud, France (in French)

13. Bondu S, Deslandes E, Fabre M-S, Berthou C, Li YG (2010) Carrageenan from Solieria chordalis (Gigartinales): structural analysis and immunological activities of the low molecular weight fractions. Carbohydr Polym 81:448-460

14. Hardouin K, Bedoux G, Burlot AS, Nyvall-Collén P, Bourgougnon N (2014) Enzymatic recovery of metabolites from seaweeds: potential applications. In: Advances in Botanical Research (N. Bourgougnon. Ed.). Academic Press 71:279-320.

15. Boulho R, Marty C, Freile-Pelegrín Y, Robledo D, Bourgougnon N, Bedoux G (2017) Antiherpetic (HSV-1) activity of carrageenans from the red seaweed Solieria chordalis (Rhodophyta, Gigartinales) extracted by microwave-assisted extraction (MAE). J Appl Phycol 29:2219-2228

16. Bedoux G, Hardouin K, Marty C, Taupin L, Vandanjon L, Bourgougnon N (2014) Chemical characterization and photoprotective activity measurement of extracts from the red macroalga Solieria chordalis. Bot Mar 57(4):291-301.

17. Boulho R, Le Roux J, Le Quémener C, Audo G, Bourgougnon N, Bedoux G (2017) Fractionation of UV-B absorbing molecules and of free radical scavenging compounds from Solieria chordalis by using centrifugal partition chromatography. Phytochem Lett 20:410-414

18. Burlot AS, Bedoux G, Bourgougnon N (2016) Response surface methodology for enzyme-assisted extraction of water-soluble antiviral compounds from the proliferative macroalga Solieria chordalis. Enz Eng 25(2). https://doi.org/10.4172/2329-6674.10001 48.

19. Peñuela A, Robledo D, Bourgougnon N, Bedoux G, HernandezNunez E, Freile-Pelegrin Y (2018) Environmentally friendly valorization of Solieria filiformis (Gigartinales, Rhodophyta) from IMTA using a biorefinery concept. Mar Drugs 16:487

20. Smith PK, Krohn RI, Hermanson GT, Mallia AK, Gartner FH, Provenzano MD, Fujimoto EK, Goeke NM, Olson BJ, Klenk DC (1985) Measurement of protein using bicinchoninic acid. Anal Biochem 150(1):76-85

21. Dubois M, Gilles KA, Hamilton JK, Rebers PA, Smith F (1956) Colorimetric method for determination of sugars and related substances. Anal Chem 28:350-356

22. Jaques LB, Ballieux RE, Dietrich CP, Kavanagh LW (1967) A microelectrophoresis method for heparin. Can J Physiol Pharm 46:351-360

23. Blumenkrantz N, Asboe-Hansen G (1973) New method for quantitative determination of uronic acids. Anal Biochem 54:484-489

24. Ho YS, McKay G (1999) Pseudo-second order model for sorption processes. Process Biochem 34:451-465

25. Langmuir I (1918) The adsorption of gases on plane surfaces of glass, mica and platinum. J Am Chem Soc 40:1361-1403

26. Mzibra A, Aasfar A, El Arroussi H, Khouloud M, Dhiba D, Kadmiri IM, Bamouh A (2018) Polysaccharides extracted from 
Moroccan seaweed: a promising source of tomato plant growth promoters. J Appl Phycol 30(5):2953-2962

27. Castro J, Vera J, Gonzalez A, Moenne A (2012) Oligo-carrageenans stimulate growth by enhancing photosynthesis, basal metabolism, and cell cycle in tobacco plants (var. Burley). J Plant Growth Regul 31:173-185

28. Murphy V, Hughes H, McLoughlin P (2008) Comparative study of chromium biosorption by red, green and brown seaweed biomass. Chemosphere 70(6):1128-1134

29. Yipmantin A, Maldonado HJ, Ly M, Taulemesse JM, Guibal E (2011) $\mathrm{Pb}(\mathrm{II})$ and $\mathrm{Cd}(\mathrm{II})$ biosorption on Chondracanthus chamissoi (a red alga). J Hazard Mat 185(2-3):922-929

30. El Nemr A, El-Sikaily A, Khaled A, Abdelwahab O (2015) Removal of toxic chromium from aqueous solution, wastewater and saline water by marine red alga Pterocladia capillacea and its activated carbon. Arabian J Chem 8(1):105-117

31. Rahman MdS, Sathasivam KV (2015) Heavy metal adsorption onto Kappaphycus sp. from aqueous solutions: the use of error functions for validation of isotherm and kinetics models. BioMed Res Intern 126298. https://doi.org/10.1155/2015/126298.

32. Di Filippo-Herrera DA, Munoz-Ochoa M, Hernandez-Herrera RM, Hernandez-Carmona G (2019) Biostimulant activity of individual and blended seaweed extracts on the germination and growth of the mung bean. J Appl Phycol 31(3):2025-2037

33. Hu X, Jiang X, Hwang H, Liu S, Guan H (2004) Promotive effects of alginate-derived oligosaccharide on maize seed germination. J Appl Phycol 16:73-76

34. Gonalez A, Castro J, Vera J, Moenne A (2012) Seaweed oligosaccharides stimulate plant growth by enhancing carbon and nitrogen assimilation, basal metabolism, and cell division. J Plant Growth Regul 32:443-448

35. Shukla PS, Borza T, Critchley AT, Prithiviraj B 2016. Carrageenans from red seaweeds as promoters of growth and elicitors of defense response in plants. Front Mar Sci 81.

36. Rathore SS, Chaudhary DR, Boricha GN, Ghosh A, Bhatt BP, Zodape ST, Patolia JS (2009) Effect of seaweed extract on the growth, yield and nutrient uptake of soybean (Glycine max) under rainfed conditions. South African J Bot 75(2):351-355

37. Safinaz AF, Ragaa AH (2013) Effect of some red marine algae as biofertilizers on growth of maize (Zea mayz L.) plants. Intern Food Res J 20(4):1629-1632.

38. Ibrahim WM (2011) Biosorption of heavy metal ions from aqueous solution by red macroalgae. J Hazard Mat 192:1827-1835

39. Michalak I, Chojnacka K (2010) The new application of biosorption properties of Enteromorpha prolifera. Appl Biochem Biotechnol 160(5):1540-1556

40. Kannan N, Sundaram MM (2001) Kinetics and mechanism of removal of methylene blue by adsorption on various carbons-a comparative study. Dyes Pigm 51:25-40

41. Michalak I, Chojnacka K, Witek-Krowiak A (2013) State of the art for the biosorption process-a review. Appl Biochem Biotechnol 170:1389-1416

Publisher's note Springer Nature remains neutral with regard to jurisdictional claims in published maps and institutional affiliations. 